PANEL 3-3

FR, JUNE 11

\title{
TOWARDS A SUSTAINABLE RUSSIAN FOREST SECTOR
}

by

\section{Lars Carlsson}

University of Lulea

(C) 1999 by author

\section{Workshop in Political Theory and Policy Analysis}

Indiana University - 513 North Park - Bloomington, IN 47408-3895 phone $8128550441 \cdot$ fax 8128553150

workshop@indiana.edu * www.indiana.edu/ workshop 
Lars Carlsson, 1999-04-15

\title{
Towards a Sustainable Russian Forest Sector
}

\begin{abstract}
Russia's forest resources are enormous but despite almost ten years of transition problems are still immense, both in terms commercial output and with respect to forest management. In this article it is suggested that one way of changing the situation is to initiate an introduction of community managed forests. Using the Swedish forest commons as an example it is argued that such a change in property rights will provide an alternative to massive privatization of the forests as well as to an undesirable continuation or strengthening of state forest management. Finally, it is concluded that such an introduction of new property rights regimes will not provide the solution to the problems but contribute to the establishing of a better institutional framework in the Russian forest sector.
\end{abstract}

Russia's forests are immense and an efficient but sensible exploitation of these resources could possibly serve as a driving force in the transition towards market economy. Although we can hardly know how a Russian market economy will or should be shaped it can be assumed that at least the following criteria must be met:

- The structure of property rights is settled, i.e., individuals get the right to utilize valuable resources for their own benefit on terms that are well defined and enforced.

- The market determines prices of property and goods.

- Private investors can realize the returns on their investments.

However, the current situation in post-Soviet Russia indicates that the overall fulfillment of these criteria is poor. Consequently, the production in all branches of the sector has decreased significantly. Before the collapse of the USSR, in 1987, the forest industrial sector was the seventh most important of all sectors in terms of industrial output. In 1996, it had fallen to the ninth position (Huber et al., 1996). Despite all attempts to establish "market mechanisms", such as the privatization of enterprises and 
the establishment of commercial banks, the situation is very problematic. A significant part of the forest enterprises only survive through subsidies or other special arrangements such as tax relief, etc.

The main lessons to be learned so far are that the old structure is hard to change and that market mechanisms cannot be imposed from above. These lessons are quite in line with Douglass North's conclusion that "although formal rules may change overnight as the result of political or judicial decisions, informal constrains embodied in customs, traditions, and codes of conduct are much more impervious to deliberate policies ${ }^{5}$ (North, 1993:6). One example from the forest sector is how "insiders" from old ministries reorganize in order to establish new platforms for their individual survival in the postsocialist society. This is a characteristic of most of the Moscow based brokers involved in the timber trade (Lembruch, 1997). These organizations serve as effective gatekeepers who prevent, for example, Siberian forest enterprises from establishing their own trading network and thereby from improving the local marketing competence.

For example in the Tomsk Oblast, a region the size of France, 58.5\% of the forest companies runs at loss (Carlssion \& Olsson, 1998:53). In this region, as well as in many other parts of Russia, whole, communities are totally dependent on the forest sector. The World Bank (1997:51) estimates that around 18\% of the workforce in the forest sector live in such areas.

The problems within the forest sector are also reflected in the level of harvesting which has fallen dramatically. For example, in Arkhangelsk, ${ }^{1}$ one of Russia's most forested areas, harvesting reached a peak in 1987/88 with a total of around 25 mill. $\mathrm{m}^{3}$. Since then, cutting has decreased significantly and, in 1996, the harvesting level was only about $29 \%$ of that of 1988 . For a long period of time the Annual Allowable Cut (AAC) was harvested in Arkhangelsk. However, due to the present problems in the forest sector the current level of harvesting is only $38 \%$ of a possible level of 21.3 mill. $\mathrm{m}^{3}$. Between 1990 and 1996 the production of commercial wood dropped from 19.4 mill, $\mathrm{m}^{3}$ to 7.2 mill, $\mathrm{m}^{3}$ and in 1994 production fell below the 1940 level.

\footnotetext{
${ }^{1}$ Figures related to Arkhangelsk are based on own research. The author of this article is a member of The Sustainable Boreal Forest Resources Project at the International Institute for Applied Systems Analysis (IIASA), Laxenburg, Austria. The Arkhangelsk study is one among a number of ongoing case studies dealing with institutional aspects of the Russian forest sector (see c.f. Carlsson and Olsson, 1998).
} 
The custom of clear-cutting in combination with poor regeneration programs was and still is - governed by the desire of getting cheap raw material coupled to an image of the forest resources as inexhaustible (Barr \& Braden, 1988). As has been reported for West Siberia and many other Russian regions a systematic over-cut has been conducted mainly along the most important transport routes (cf. Carlsson and Olsson, 1998). However, this type of local over-cutting has sometimes been "compensated for" and thereby hidden in the statistics by an undercutting in other areas. According to estimates made by Pisarenko and Strakhov (1996) in a number of areas the level of over-harvesting was found to be around $35 \%$. Due to a general scarcity of resources, state forest authorities lack means to monitor the actors and to implement the new forest code as well as other environmental regulations.

Thus, it can be concluded that the Russian forest sector is far from being effective and that a number of changes must be made in order to make it as prosperous as it could be. These changes might range from a general technological renewal or a reorganization of the forest management to the alternating of institutional and constitutional features of the Russian forest sector (cf. Nilsson \& Shvidenko, 1998).

In the Soviet Union practically all forest resources belonged to and were managed by state authorities. This system reached its peak in the first years of the 1970s. The institutional history of the system has been scrutinized in many publications and need not be recapitulated here (see e.g. Nove, 1977; Blandon, 1983; Barr \& Braden, 1988; Kaminski, 1992; Sheingauz et al., 1995; World Bank, 1997).

Today, almost no forestlands have been privatized and the current property rights situation with respect to the Russian forests is unclear. The forests belong to the state, but it is not clear to which part of it they belong. The forest code states that the forest resources are jointly owned by the "Russian Federation and the Subjects of the Russian Federation." Accordingly, the forestlands of single oblasts etc. belong to the Russian federation as well as to the oblast. This ambiguous situation did not change with the new forest code adopted on January 22,1997.

The current situation in the Russian forest sector can be summarized as follows: 
- Despite abundant forest resources there is a shortage of timber for the big industries while at the same time the internal and external demand for wood is weak.

- There is a lack of congruence between central and regional levels of decision-making related to the forest sector.

- The forest management system is poorly funded, e.g., forest fire protection and regeneration programs are severely effected.

- Even though new rules of forest management and protection are enacted there is a . general lack of mechanisms for their implementation.

- The timber price is artificially low, transportation fees and taxes are immense, internal and foreign trade is undeveloped.

- Corruption and criminalization of the sector is significant.

- Degradation and devastation of forest resources continue.

- A significant number of firms run at a loss.

- An increase in the practice of barter, rent seeking and a wide spread custom of negotiating for privileges prevent the firms from acting as commercial actors thus promoting the market system.

What can be done to solve these problems? In this article it is argued that one such change, which presumably will have a profound influence on the development, is to alter the present situation of property rights. This can be done in many ways. Privatization of the forests is only one option. In this article it is not argued, however, that all forestlands should be privatized. Rather, Russian authorities might do better to introduce new models of property rights regimes that both connect to the strong collective element in the Russian tradition and which have demonstrated their viability and resilience over a significant period of time in other parts of the world. In this respect the communitymanaged forests in Sweden offer some interesting historical experiences.

\section{Moving Away from State Management?}

Although Germany, Scandinavia and many other countries provide good examples of successfül state management of forest resources the lessons from the former Soviet Union are not encouraging. A continuation of or a new but strengthened influence of state 
management in Russia is unlikely. For example, one of the main problems in contemporary Russia, and indeed also in the forest sector, is that even if intentions are good the authorities lack the means of implementing rules and regulations. At the same time a total privatization of the Russian forest fund might turn the sector into a robber economy, with national and international actors squeezing the juice out of the fruit leaving nothing but environmental disaster behind (cf. Nilsson and Shvidenko, 1998:46 ff). Due to low or non-legitimacy for such a privatization this would surely cause severe political unrest among the Russian people. This is not in itself an argumentation against privatization, but only to emphasize the fact that Russia lacks an institutional framework that is able to handle such a dramatic change in property rights. In fact, a general problem with many of the proposed measures for improving the situation in Russia is that they presuppose the existence of an already well functioning institutional framework.

Such a framework might be the outcome of the current transition and, thus the result of interaction among people engaged in repeated activities along more market-oriented lines, in democratic associations, etc. However, it should be emphasized that "the prevailing institutional framework in a society consists of formal and informal rules" (Pejovich 1998:23). These "rules of the game," i.e., institutions (North, 1990; Crawford and Ostrom, 1995), constitute a basic prerequisite for the future development of the Russian forest sector. Such rules are not only established by means of political, administrative decisions, however.

While institutions consist of the rules that people actually follow, particular institutional arrangements at the same time compel them to act in certain ways. This has to do with qualities of institutions as rule-ordered entities. Thus, a basic assumption behind any suggestion to change institutional arrangements is that institutions affect strategic choice and that the behavior of each actor depends on their expectation of what others may do (cf. Coleman, 1988, 1990; Knight, 1994; Benham, et al, 1995). The same way as the institutional arrangements of the forest sector in the former Soviet Union compelled its actors to behave in specific ways this will happen also if vital markets emerge. 
The manner in which people are affected by the market as an institution is not merely that it provides information, or merely constraints, but that it structures the process of cognition of the agents involved and can actually affect their preferences and beliefs. Thus in a subtle way, through the operation of market conventions, routines and rules, the individual in the market is to some extent 'coerced' into specific types of behavior (Hodgson, 1989:179).

Given this as a background, what might be the benefits of detaching some of the Russian forest resources for communal ownership and management and what would such a property rights regime look like?

\section{Community Managed Forests, Living History}

In Sweden, community managed forests; named forest commons, were established more than one hundred years ago. ${ }^{2}$ The purpose of this was dual. The first reason was to prevent forest companies from unsustainably exploiting the forest fund and thereby ruining the farmers. The second, but related aim, was to strengthen the local economy and thus to establish a solid basis for taxation. The first community managed forest was established in 1862. All subsequent units got, and still have, virtually the same organizational form. Overall, the commons is the sixth biggest forest owner in the country.

Every unit is based on a number of single farmers, often about one thousand individuals. ${ }^{3}$ In addition to their private lands these farmers hold shares in a bigger, jointly owned area. The biggest of these commons possess around 60,000 hectares of forestlands. In this way each farmer is the legal owner of a private piece of property, his farm, as well as a certain amount of shares in a common. Even though the farmers jointly own the commons they are not cooperatives, however. Most farmers have about the same number of shares but bigger farmers often have more. It is worth noting that the shares are coupled to the farm and cannot be separately traded. This organizational form is a mix of collective and private property rights which gives the system some advantages that will be discussed later.

\footnotetext{
${ }^{2}$ Here we pay no attention to the fact that the organizational structure of the commons dates back to medieval times.

${ }^{3}$ Note that being a farmer was also associated with ownership of forestlands. Today the ownership structure is more heterogeneous but still farmers constitute the major group.
} 
Each common is regulated by its own by-law (approved by the assembly of the shareholders and the state authorities) and a special law governs all 33 units. Among other things, this law stipulates that the forest area must not be diminished and that each unit must appoint some person with professional knowledge in forestry, typically a forester.

In each common the assembly of shareholders, among themselves, elects a board, which, together with the appointed forester, governs the unit. Although bigger shareholders have more votes in the assembly there are rules that prevent dictatorship. Most units function as forest companies: they harvest their timber, cultivate their resources and distribute their profits among the owners. Two principles, often working in parallel, exist for distributing the revenue. The first is to distribute the profit as annual cash dividends to the farmers in accordance to their possession of shares. A second way of distributing the profit is to "subsidize" farmers for the investments they make on their own private farms. For example, farmers are reimbursed per hectares of regenerated land, for draining, rebuilding of barns and cowsheds. The principles for this subsidizing are decided by the assembly of shareholders and vary among the units. In many commons a significant part of the profit is spent on the maintenance of public and private roads.

These ways of strengthening the local economy have historically been very important. For example, the commons have been very important contributors to the electrification of the northern countryside, the establishing of dairies, insemination stations, etc. The forest commons still run local sawmills, power plants and other subsidiary enterprises for the benefit of the areas in which they operate. During the course of time the policy has gradually been changed from supporting farming to forestry.

\section{The Performance of Community Forest Management}

To argue that the Swedish concept of forest commons would be beneficial for the Russian forest sector requires some kind of underpinning. Would not "the tragedy of the commons" (Hardin, 1968), i.e., a devastation of the resources be a more likely scenario? A historical example might indicate the opposite.

Figure 1 contains some unique historical data from two adjacent and equally sized forests with different management systems and ownership, Orsa forest common and 
Hamra state forest. As can been seen in the diagram there was a dramatic reduction of the resources in the Orsa, actually a halving of the volume in ten years, just before the turn of the century. This period is called the "dimension felling" meaning that much of the old and overmature trees were cut. ${ }^{4}$ However, due to deliberate regeneration there has been a steady restoration of the resource. In the adjacent state forest, however, the volume continued to decrease through the next 70 years! How can this be explained?

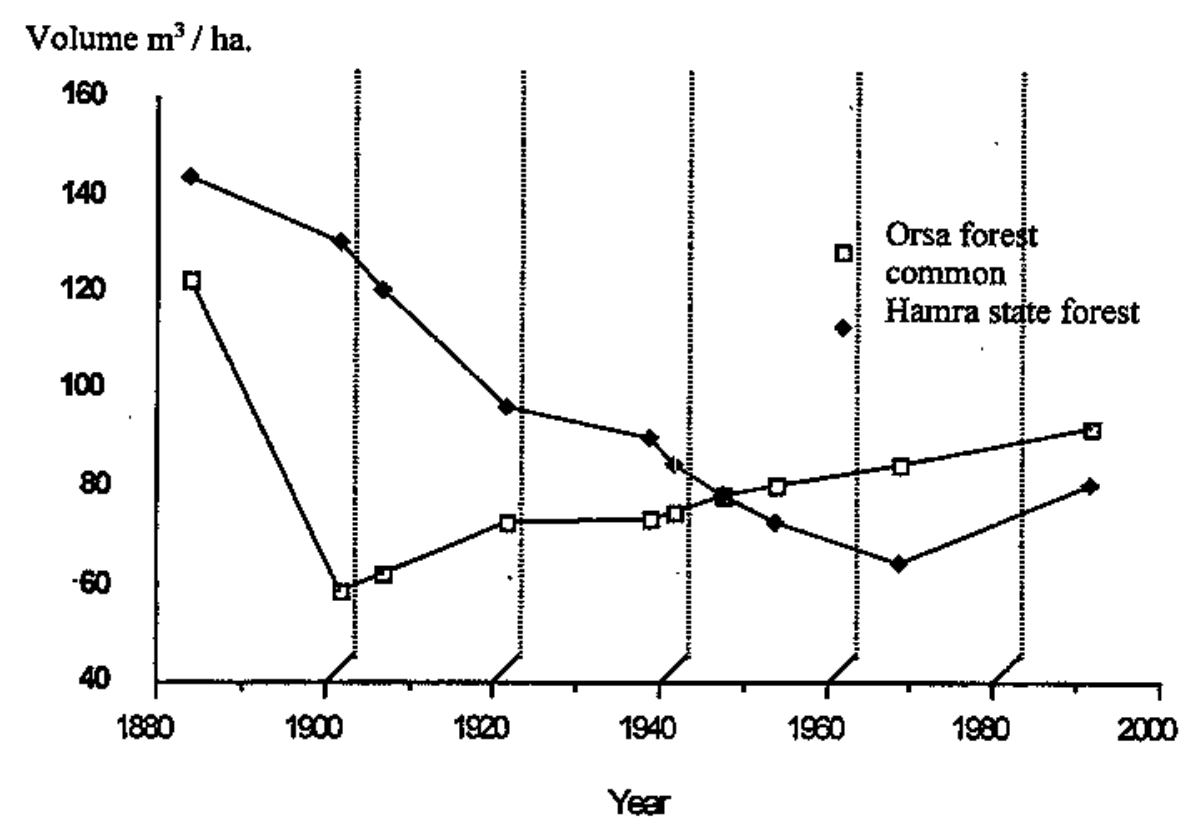

Figure 1. Forest resources in Orsaforest common and Hamra state forest (Source: Linder and Östlund, 1992:203)

Hamra State forest was managed by the State Forest Service in line with a centrally decided management policy based on scientific doctrines of the time (Östlund, 1993, Ch. 4, p. 7). It should be emphasized, however, that both units operate under the supervision of the same type of professional foresters educated at the same Swedish school of forestry. The manual workforce was recruited among local farmers, who provided horses and men under the cutting season. Therefore, there were no differences in the quality of

\footnotetext{
${ }^{4}$ It might be worth mentioning that the situation that triggered the "dimension felling" was similar to much of the forests in contemporary Russia where huge areas contain unexploited and overmature stands.

(Nilsson and Shvidenko, 1998: 10)
} 
labor or technology that operated in the Swedish forests at that time (Lundgren, 1984). The big difference is the ownership and organization of the units, and presumably this had decisive effects.

Unlike to the State managers who managed Hamra state forest, the farmers who had established Orsa forest common were directly dependent on the productivity of the forest. For example, the inhabitants in Orsa paid no municipal taxes until the Second World War. The forest common contributed all the resources that were needed for public works and services. The forest was their savings account and the increment their interest rate. What would they and their successors eventually live off when all the trees were gone for at least 100 hundred years? The state forest can be assumed to operate according to another logic and with a significant information delay from the local level to central decision-makers. No one, except perhaps the taxpayers, would have any personal incentive to bother about forest productivity. Thus, "state governance does not necessarily ensure sustainable use. Given that the officials who make decisions do not have the same time horizon or interests as private owners, the general public, or the government itself, this is not surprising" (Feeny et al. 1990:11). ${ }^{5}$ Moreover, èven a debatable forest management provides people with working opportunities, at least in a short-term perspective. The latter comment is also valid for the forest sector in today's Russia.

Recent research indicates that over a significant period of time the Swedish forest commons have adopted a policy based on the idea of a "target income" (Carlsson, 1999). Such a policy has the effect that the community-managed forests have a tendency to harvest less when timber prices rise. Whether this behavior reflects a concern for the forest resource or whether it is simply an effect of the fact that farmers might prefer to sell timber from their own private lands in times with high prices is hard to decide. The result is the same however, namely, that the commons provide a sustainable yield at levels way under the annual increment (Carlsson, 1998:85). Finally, it should be emphasized that the community-managed forests are regarded by experts as well

\footnotetext{
${ }^{5}$ It should be emphasized that it is not argued that the behavior in Orsa is "good" while the behavior of Hamra state forest's is "bad." If sustainability means a preservation of the biomass that happened to exist in 1880 both actors have failed. However, compared with the situation in 1890 the common has lost less of its volume.
} 
managed and that they show an environmental concern that is in line with, or better than, other forest owners. ${ }^{6}$ In the next section it will be discussed to what extent the Swedish experiences might be useful in the Russian context.

\section{Benefits of Introducing Community Management in Russia}

In many places in Russia it might be convenient to detach land for community managed forests. The big hurdle, however, seems to be that Russia virtually lacks a class of (or inheritors from) small farmers around which a community managed system could be created. There are exceptions however, for example in Karelia. Until 1996 the reform period had resulted in more than 280,000 new, small, and privately owned, or leased, farms (Rolfes, 1996). It might also be remembered that many shareholders in the early Swedish commons in fact we settlers on state forest lands. Although they lacked own experiences of ownership of land they were skilled in agriculture and forest work similar to the situation in today's Russia.

It should be emphasized, however, that even a community managed system in Russia requires a potent state, a stable economy, a good infrastructure, and so forth. One of the basic advantages with the suggested change in property rights is that it might help to contribute precisely this. Such a change in property rights would give single players an increased incentive for long term planing, to prevent free riding and corruption. In the long run the system is believed to contribute to the establishing of a stable and well functioning institutional framework that is so badly. needed in the Russian forest sector. The arguments for these assumed positive effects are several:

- A community-managed system is to be regarded as a compromise between a continuation of a collective tradition in the Russian society and the contemporary policies of privatization and market economy. One might also say that the system, at least in some places, would pick up a pre-Soviet tradition of small, private farming within a context of strong village community. Thus, the likelihood for legitimacy, and commitment for this new system could be expected to be rather high.

\footnotetext{
${ }^{6}$ This statement is based on interviews with experts from the State Forest Service in all the districts where community forests are located (Carlsson, 1995). The Swedish Commission on Collectively-Owned Forest Lands (Ds 1984: 15) came to the same conclusion.
} 
- The system is based on private ownership; something that will give the shareholders an incentive to cultivate the resource and to generate profit.

- The requirement of appointing professional foresters will make the forests managed in accordance with professional standards, a knowledge single farmers typically lack. The present systems of Leskhozy, i.e., the regional units of the Russian Federal Forest Service, are poorly funded but may provide excellent personnel. ${ }^{7}$ The fact that former Forest Service people operate in other entities should not be underestimated. For example, this type of connection is important for the implementation of new standards and rules among the forest owners as well as for the monitoring by the forest authorities. ${ }^{8}$

- While the single shareholding farm typically is small the community forests are big. Thus, there are economies of scale in that the common might have resources, and make investments that the private farmer is unable to do. The experiences from Sweden show that the commons have succeeded fairly well to keep up with technology and compete in the timber market.

- A system of community managed forests might provide practical examples of welldefined property rights. Such a system, well tailored, would fulfill some basic criteria for sustainable institutional arrangements for the handling of natural resources. That is, access to, and appropriation of, resources are well defined, rules are decided by the same people that are affected by them, monitoring and sanctioning are executed on behalf of the owners, ${ }^{9}$ often to very low costs, and so forth (for an elaborated discussion, see Ostrom, 1990, 1992; Bromely, 1992).

- Finally, an experiment with the introduction of community managed forests in Russia might also contribute to the fostering of rules and norms that economic history have told us are conducive for market economies but which have been absent for such a long period of time in Russia. Reciprocity, trust, and predictability are three catchwords for this. Community managed forests in modern society are business

\footnotetext{
${ }^{7}$ The Russian Federal Forest Service is built on the German and Swedish way of organizing state forest management (Klose, 1985). In 1998, the organization celebrated its 200-year anniversary.

${ }^{8}$ Many Swedish commons have employed former Forest Service experts, but in some cases the commons simply buy the professional service from the authorities.

${ }^{9}$ For example, distribution of subsides require an internal system of control and infringements can be punished by means of withdrawal of economic support, and so on.
} 
entities. These entities will have to base their possible success on the establishing of personal as well as commercial relations with numerous actors. Social capital might be expected to be built up that in the long run will enhance predictability and thus the institutional framework of the forest sector. Successful commercial behavior requires trust and openness with regard to the rules of the game. If in the future community managed forests succeeded in that respect they might serve as a positive example for rest of the sector.

\section{Conclusion}

The specific situation of the Russian forest sector gives rise to some doubts about some of the mainstream solutions to the problems it currently faces. State management has demonstrated its shortcomings and a sudden privatization of forestlands would probably cause even more trouble. Community managed forests have been proven to provide a midway out of the problem. Exactly how these entities should be configured requires more careful consideration. The basic question to be decided is who or what actors should constitute the building blocks of such a system. For example, it is really an openended question whether the basic unit should be single farmers only? A number of other possible owners exist, such as, sawmills, crafts industries, and processing units. Here one should pay great attention to local and historical circumstances in different parts of Russia.

The greatest hurdle, however, is the fact that the introduction of the type of change in property rights that is proposed in this article also requires a legitimate decision-maker. Who should make such a decision? This question cannot be unambiguously answered, however. Two options exist. The first is that the State Duma straightens out the collision between the constitution and subsequent regulations, e.g. by allowing privatizing some of the forestland. The other alternative would be for the Oblasts etc. to grab the opportunity that is provided by the weak state and expand their influence. This means that they simply should decide to allocate forests for the purpose of creating community managed 
unites based on private ownership of land. This kind of behavior is already a reality in several parts of the federation. ${ }^{10}$

Only to the extent formal political, administrative arrangements are in harmony with already existing informal institutions legitimacy can be expected. Thus, the big problem for Russian policy makers is not only to make adequate decisions that might change these institutions but to find solutions that have a fair chance to be accepted among the actors of the forest sector as well as among broader segments of the Russian population. Presumably the introduction of community managed forests may fulfill these criteria.

Finally, an introduction of community managed forests should not be regarded as the solution to all problems in the Russian forest sector. It might be one among a number of different efforts to come to terms with the present situation of ambiguous property rights. All successful forest countries have a number of different management forms simultaneously in operation.

\footnotetext{
${ }^{10}$ See Carlsson and Olsson, 1998:57, footnotes 33 and 34. For example, on September 29 Russia Today reports that the Governors from Kaliningrad and Krasnoyarsk had "annoyed Kremlin by announcing their own plans to take control over economic policy" (http://www.russiatoday.com). On October 22 the governor of Sverdlovsk launched the idea of issuing a local currency (Russkii Telegrafas reported in IEWS Russian Regional Report, Internet Edition, Vol. 3, No. 42,22 October 1998).
} 


\section{References}

Barr, Brenton and Kathleen E. Braden (1988) The Disappearing Russian Forest. London: Rowman \& Littlefield.

Benham, Alexandra, Lee Benham and Michael Merithew (1995) "Institutional Reform in Central and Eastern Europe: Altering Paths with Incentives and Information." Research report, St. Louis: International Center for Economic Growth, Washington University.

Blandon, Peter (1983) Soviet Forest Industries. Boulder Ca: Westview Press.

Bromely, Daniel W., ed. (1992) Making the Commons Work. San Francisco: ICS Press.

Carlsson, Lars (1995) Skogsallmdnmingarna i Sverige. (Forest Commons in Sweden.) Research Report, TLULEA 1995:22, Luleå University, Sweden.

_ _ _ (1998) "The Swedish Forest Commons: Challenges for Sustainable Forestry," in Sandberg, L Anders and Sverker Sörlin, Sustainability the Challenge. Montreal: Black Rose Books, pp. 80-89.

_ _ _ (1999) "Still Going Strong, Community Forests in Sweden." Forestry, Vol. 72(1), pp. 11-26.

Carlsson, Lars and Mats-Olov Olsson, eds. (1998) Initial Analyses of the Institutional Framework of the Russian Forest Sector, IIASA Interim Report (IR-98-027), Laxenburg, Austria: International Institute for Applied Systems Analysis, June.

Carlsson, Lars and Mats-Olov Olsson (1998) Institutions and the Emergence of Markets, Transition in the Tomsk Forest Sector. IIASA, Interim Report, IR-98-084/October.

Coleman, James, (1988) "Social Capital in the Creation of Human Capital". American Journal of Sociology, Vol. 94, Supplement S95-S20.

Coleman, James, (1990) "Norm-Generating Structures," in Cook, K. S. and M. Levi., The Limits of Rationality. Chicago: The University of Chicago Press, pp. 250-273.

Crawford, Sue E.S. and Elinor Ostrom (1995) "A Grammar of Institutions." American Political Science Review, 89(3), September, pp. 582-600.

Feeny, David, et al. (1990) "The Tragedy of the Commons: Twenty-Two Years Later", Human Ecology, Vol. 18, No 1, pp. 1-17.

Hardin, Garrett (1968) "The Tragedy of the Commons." Science, Vol. 162, pp. 12431248.

Hodgson, Geoffrey M. (1989) Economics and Institutions. Cambridge: Polity Press.

Huber, Peter, Sergei Nagaev and Andreas Worgotter (1997). Tomsk - A Regional Approach to Industrial Restructuring, Interim Report - April 1997. Vienna; Institute for Advanced Studies.

Kaminski, Antoni Z. (1992) An Institutional Theory of Communist Regimes. San Francisco: ICS Press.

Knight, Jack (1994) Institutions and Social Conflict. Cambridge: Cambridge University Press.

Klose, F. (1985) A Brief History of the German Forest, Achievements and Mistakes Down the Ages. Eschborn: Deutche Gesellschaft für Technische Zusammenarbeit (GTZ). 
Lehmbruch, Barbara (1998) "Institutionalized Uncertainty: Economic transformation the Russian Timber Industry from 1992 to the Present' in Lars Carlsson and MatsOlov Olsson (eds.) Initial Analyses of the Institutional Framework of the Russian Forest Sector, IIASA Interim Report (IR-98-027), Laxenburg, Austria: International Institute for Applied Systems Analysis, June.

Linder, Per and Lars Östlund (1992) "Förändringar i norra Sveriges skogar." Svensk Botanisk Tidskrift, No. 86, pp. 199-215.

Lundgren, Nils-Gustav (1984) Skog för export Umea Studies in Economic History 6. Umeå: Umeå University.

Nilsson, Sten and Anatoly Shvidenko (1998) Is Sustainable Development of the Russian Forest Sector Possible. IUFRO Occasional Paper No. 11, ISSN 1024-414X.

North, Douglass (1991) Institutions, Institutional Change and Economic Performance. Cambridge: Cambridge University Press.

Nove, Alec (1977) The Soviet Economic System. London: George Allen \& Unwin Ltd.

Ostrom, Elinor, (1990) Governing the Commons. New York: Cambridge University Press.

_ _ _ (1992) Crafting Institutions for Self-Governing Irrigation Systems. San Francisco: ICS Press.

Pejovich, Svetozar (1998) Economic Analysis of Institutions and Systems. London: Kluwer Academic Publishers.

Pisarenko, Anatoly L; Valentin V. Strakhov (1996) Socio-Economic Assessment of the Russian Boreal Forests, IIASA Working Paper (WP-96-58). Laxenburg, Austria: International Institute for Applied Systems Analysis, July.

Rolfs, Jr. Leonard J. (1996) "The Struggle for Private Land Rights in Russia " Economic Reform Today, Internet version, http://www.cipe.Org/e 19/rolfes.html, 22 October, 1998.

Sheingauz, Alexander, Sten Nilsson and Anatoly Shvidenko (1995) Russian Forest Legislation. IIASA Working Paper (WP-95-45), Laxenburg, Austria: International Institute for Applied Systems Analysis, May.

Skogsallmdnningar Ds Jo 1984:15. (Forest Commons) The Swedish Commission on Collectively-Owned Forest Lands Ds Jo 1984:15.

World Bank (1997) Russia; Forest Policy during Transition. A World Bank Country Study, Washington, D.C.: The World Bank.

Östlund, Lars (1993) Exploitation and Structural Changes in the North Swedish Boreal Forest 1800-1992. Dissertations in Forest Vegetation Ecology 4, Sveriges Lantbruksuniversitet, Umeå. 